\title{
EDITORIAL
}

\section{SECURITY FORCES OF THE FUTURE}

We will conclude the year 2017 by addressing the topic of security forces of the future. The future is difficult to predict, guess or anticipate, however, some individuals, institutions and corporations are investing efforts in this.

Yuval Noah Harari published a book on future, titled Homo Deus - A Brief History of Tomorrow. In this book, he foresees that in the future, we will primarily fight against death. This should be the main guideline for the development of future generations.

The fundamental guideline for the development in the field of security forces is not exactly a topic to fill the headlines of daily newspapers, let alone is this a topic that would make bestsellers on publishers' book shelves. But it is, however, a topic that has been forever present in the fields dealing with the provision of security. Consequently, in December, Permanent Structured Cooperation (PESCO) was established within the framework of the European Union with the aim to contribute to better cooperation of EU member states in training, capability development and operational readiness within the framework of defence. This was a reaction to the security situation in Europe, taking into account our immediate and extended neighbourhood, which has been discussed by many authors in the previous issues of Contemporary Military Challenges.

It may be too early to determine the role of Slovenia in PESCO. Nevertheless, it is imperative that we commit ourselves to this topic seriously and responsibly. Not only to this topic, however. We must seriously begin to discuss Slovenia's security future. A while ago, we were surprised by the floods; in 2014 we were surprised by glaze ice and in 2015, by the European migrant crisis. What have we learned from these experiences? How many panels and other discussions have been organised on these topics, how many proceedings have been published, how many articles have been written? How many changes have we made in the national security system and how well prepared are we for new challenges? 
When we were preparing to join the European Union and NATO, we organized ourselves systematically, prepared a media campaign, and enjoyed the political support and substantial public support to achieve the goal. Whatever happened in this country that we no longer devote a pragmatic level of attention to personal and collective security? A lot has happened. Much has been written and said about this, but still...

The fact is that our opinions, views and ideas in the field of security and defence differ, which is alright.

In the Editorial Board of Contemporary Military Challenges, we decided to dedicate this issue to security forces of the future with an emphasis on Slovenia.

Taking into account the geographical location of Slovenia, Viktor Potočnik focused on the Anti-armour combat in the Slovenian Armed Forces, providing an answer to the question of what and how much equipment Slovenia needs in this field in order to functionally provide for its security.

In his article entitled Contributions to the analysis of challenges, future development and scope of armed forces in Slovenia, Alojz Šteiner writes that although Slovenia is in the midst of the processes concerning design, programming and normative regulation of the defence and military system, he believes that a re-analysis or an interim analysis is necessary. He draws attention to the need for a reflection on open issues and adds his opinion on what these challenges are.

In his article Military strategic reserve and the transformation of modern armed forces Vinko Vegič discusses the need for a thorough assessment of the military concept of the military strategic reserve. According to the author, the concept of a military strategic reserve is not consistent with the transformation of modern armed forces, its feasibility, and the wider social concept.

Miha Šlebir responded to the articles by Kotnik, Potočnik and Žurga published in the last issue of 2016. In his article entitled Guns vs. butter? Comparative analysis of Slovenia's defence expenditure explains the trend of financing and allocation according to areas within the armed forces of EU member states and what this can mean for Slovenia and its armed forces.

Roman Faganel and Dragomir Čevriz indirectly reacted to the article by Tom Young published in the last issue of 2016. Analytical approach to resource planning and decision making in the defence system is the title of an article that brings theoretical starting points with a quantitative case study analysis.

Reliability of individuals in the operation of a modern state critical infrastructure is the article by Brane Bertoncelj, who presents the framework of the model of influence an individual's reliability has on the functioning of the critical infrastructure of a 
modern state. He notes that the reliability of an individual in unusual circumstances is most dependent on the level of their motivation, competence and affiliation to the organization.

We expect to incur interest for a debate on the subject of security forces of the future, which includes numerous topics and at the same time motivate some of you to write articles on topical issues in the field of security, defence and warfare to be published in 2018 editions of Contemporary Military Challenges. 